Nevenka Bevc

Nova Ljubljanska banka, Ljubljana

\title{
Usposabljanje zaposlenih za prenos znanja - interno izobraževanje in izobraževanje izobraževalcev
}

\section{ORGANIZACIJA INTERNEGA IZOBRAŽEVANJA}

Izobraževalni center NLB ima za seboj 27 let delovanja. Osnovni razlog za njegovo ustanovitev je bila potreba po določenih vrstah znanja in veščinah s področja bančništva, ki je takratni šolski sistem ni mogel zadovoljiti.

Postavitev lastnega izobraževalnega centra je omogočila organizacijo posvetov, seminarjev

Prenos znanja spodbuja predvsem uradno sprejeta kadrovska politika. in delavnic, na katerih so se imeli priložnost srečevati interni strokovnjaki $\mathrm{z}$ različnih področij bančnega poslovanja in tako izmenjavati znanje ter izkušnje.
NLB se v obdobju privatizacije in vključevanja v Evropsko unijo še bolj zaveda, kako pomembno strateško prednost bo imelo $\mathrm{v}$ prihodnjih letih prav znanje zaposlenih.

Organizacijska kultura zato omogoča in spodbuja izobraževanje slehernega zaposlenega.

Tako je uprava leta 1996 sprejela kadrovsko politiko, v kateri je področju izobraževanja oziroma posredovanju znanja namenjena posebna pozornost. Postavili smo si naslednje temeljne cilje:
- zagotavljati organiziran in sistematičen prenos znanja in izkušenj izbranih, posebej motiviranih ter usposobljenih bančnih delavcev na sodelavce prek Izobraževalnega centra in v okviru OE;

- zagotavljati, da poslovna praksa banke, dolgoletne izkušnje, postopki, ideje, tehnološke in razvojne rešitve ter problemi ostajajo $\mathrm{v}$ banki in se ne uporabljajo pri izobraževanju kadrov konkurenčnih bank;

- zagotavljati pravočasno pripravo in prenos znanja $v$ sistematični in organizirani obliki pri vsakem prenosu poslov oziroma pri uvajanju novih storitev ali tehnoloških rešitev;

- zagotavljati sprotno prenašanje pridobljenega znanja $v$ tujini in zunanjih institucijah drugim zaposlenim s prezentacijami, diskusijami, okroglimi mizami in uporabo internih elektronskih medijev (intranet) ipd.

Pri uresničevanju zastavljenih ciljev spodbujamo identificiranje, motiviranje in usposabljanje zaposlenih za prenos znanja in pridobitev naziva predavatelj ali mentor NLB. Ta naziv pridobijo interni izobraževalci, ki upoštevajo in udejanjajo standarde in merila za izvajalce. Podelitev nazivov organiziramo vsaki dve leti, pridobljeni naziv je posameznikova trajna last in eden od meril za njegovo napredovanje. 
Metode in tehnike izobraževanja ter usposabljanja zaposlenih $\mathrm{v}$ NI.B:

1. uvajamø spremembe $z$ izobraževanjem »od vrha navzdolk;

2. zagotavljamo izobraževalne programe za pridobivane temeljnega, poglobljenega in specialističnega znanja;

3. razvijamo izobraževalne programe za učenje z osebnim doživljanjem;

4. za doseganje večjih uěinkov pri delu pripravljamo tudi programe za utrjevanje že pridobljenega znanja;

5. razvijamo petstopenjski model, ki vodi k povečevanju uporabe pridobljenega znanja in veščin v praksi.

\section{USPOSABLJANJE NOTRANJIH IZOBRAŽEVALCEV}

Strokovni delavci Izobraževalnega centra in vodje posameznih organizacijskih enot so ves čas delovanja centra sistematično spremljali posredovanje znanja ter veščin in oblikovali seznam tistih izobraževalcev, ki so se pri tem najbolj izkazali, uporabili najprimernejše metode in oblike dela ter pokazali tudi precejšnjo pripravljenost za opravljanje tega »dodatnega dela.

V želji, da se zviša kakovost posredovanja znanja in s tem tudi zadovoljstvo ter motivacija udeležencev izobraževanja, ter navsezadnje tudi kot pomoč internim izvajalcem, smo pred leti začeli razmišljati o pripravi in izvedbi izobraževalnega programa, s katerim se bodo usposabljali interni izobraževalci.

$\mathrm{V}$ tistem času je NLB veliko sodelovala $\mathrm{z}$ AIB - banko iz Dublina na različnih področjih bančnega poslovanja in njihovimi svetovalci za interno izobraževanje. Svetovali so nam, da po njihovem vzoru najprej usposobimo manjšo skupino internih izvajalcev, ki bodo pridobljeno znanje in veščine lahko posredovali drugim. Program usposabljanja je bil zamišljen tako, da so udeleženci v prvem tednu pridobivali znanje in veščine o novih oblikah ter metodah dela $\mathrm{z}$ odraslimi, v naslednjem tednu pa pripravljali prezentacije in treninge $\mathrm{z}$ vsebinami s svojega področja dela. Te izkušnje in sodelovanje $\mathrm{z}$ njihovo trenerko so se izkazale za uspešne in prepričani smo bili, da bodo »usposobljeni« trenerji kmalu začeli prenašati pridobljeno znanje in veščine na druge izvajalce. Objektivne okoliščine so pripomogle k temu, da je bil časovni razmik prevelik, zato je pozabljanje naredilo svoje.

Potreba po usposabljanju internih izobraževalcev pa se je z leti povečevala, kot se je povečevalo število izobraževalnih programov ter delavnic in s tem tudi število udeležencev.

Na slovenskem trgu smo poiskali usposobljenega trenerja, ki je v sodelovanju z Izobraževalnim centrom ter vodji pripravil in izvedel trening za tri skupine udeležencev. Te smo izbrali tako, da smo povabili po enega udeleženca s posameznega področja dela v banki.

Tako se je v banki usposobila skupina 45 internih izvajalcev.

Usposabljanje in nenehno izpopolnjevanje internih izvajalcev s tem seveda ni končano, saj se poleg te skupine trenerjev naših izobraževalnih programov, na katerih »pilijo« svoje prezentacije in nastope, udeležujejo tudi drugi izvajalci, ki želijo izboljšati kakovost svojih izvajanj.

Poleg tega, da banka nagradi pripravljenost posameznikov za prenos znanja, še posebej nagradi kakovost pri tem delu, tako da vsaki dve leti podeljuje naziv predavatelj in mentor NLB. Pridobi ga lahko izvajalec, ki upošteva standarde za izvajalce, dalj časa sodeluje na področju posredovanja znanja z Izobraževalnim centrom in ki ga udeleženci ocenijo odlično.

V letu 1996 smo prvič podelili nazive in doslej je pridobilo naziv predavatelj NLB 28, naziv mentor pa 15 zaposlenih. 
V letu 2000 načrtovano podelitev smo premaknili v letošnjo jesen in skupina nosilcev naziva se bo še povečala.

\section{SKLEPNE MISLI}

$\mathrm{V}$ času privatizacije in vključevanja Slovenije v Evropsko unijo se v NLB še bolj zavedamo, da bomo svojo konkurenčno prednost obdržali ali celo povečali samo $\mathrm{z}$ odlično usposobljenimi kadri.

Zavedamo se tudi, da bomo to lahko dosegli s stalnim strokovnim izpopolnjevanjem vseh zaposlenih in da bomo morali biti pri tem ra-

\section{Za učinkovit prenos znanja $v$ organizaciji lahko poskrbijo lahko le izkuseni izobraževalci.} cionalni $\mathrm{z}$ vidika sredstev, $\mathrm{ki}$ jih namenjamo izobraževanju, in časa, ki ga za to namenjamo.

Ključno priložnost za izpolnitev tega cilja vidimo predvsem $\mathrm{v}$ izobraževanju internih izobraževalcev, ki bodo pridobljeno znanje posredovali drugim, bodisi neposredno na delovnem mestu, seminarju, delavnici bodisi v drugih oblikah.

Zato nameravamo tudi v prihodnje precej pozornosti posvetiti »odkrivanju« novih internih izobraževalcev in izpopolnjevanju sedanjih.

Drugo priložnost pa vidimo $\mathrm{v}$ iskanju novih oblik in metod dela, ki bodo še »prijaznejše « do naših zaposlenih, predvsem v tem smislu, da si bodo lahko sami izbrali čas za učenje. Razvijamo namreč kar nekaj programov za samoučenje. 